\title{
PROACTIVE HABITAT RESTORATION AND THE AVOIDANCE OF ADVERSE EFFECTS ON PROTECTED AREAS: DEVELOPMENT PROJECT REVIEW IN EUROPE AFTER ORLEANS
}

\author{
Hendrik Schoukens ${ }^{\text {a }}$
}

\section{Introduction}

The ports of Europe are major logistic trading hubs and have been so since the Middle Ages taking in, storing, and dispatching goods and cargo from all over the world to the continental hinterland. With economic globalization and the growing importance of climate change and security threats in recent decades, the value of ports for Europe's economies has increased and will continue to do so. ${ }^{1}$ Ports are major engines for growth in Europe ${ }^{2}$ and handle $90 \%$ of the continent's international trade. ${ }^{3}$ Many port authorities are understandably eager to expand to fully realize their growth potential and adapt to new developments in international maritime commerce. Such expansion will give rise, however, to significant environmental impacts, such as habitat destruction, harmful emissions, and water pollution, often exacerbating the already degraded status of vulnerable estuarine ecosystems. This means that new port development must

${ }^{\text {a }}$ Department of European, Public and International Law, University of Ghent, Belgium. Contact: Hendrik.Schoukens@UGent.be.

${ }^{1}$ European Commission, Strategic Goals and Recommendations for the EU's Maritime Transport Policy Until 2018, COM (2009) 8 final (Jan. 21, 2009).

${ }^{2}$ European Commission, Ports: An Engine for Growth, COM (2013) 295 final (May 23, 2013).

${ }^{3}$ European Commission, An Integrated Maritime Policy for the European Union, COM (2007) 575 final (Oct. 10, 2007). 
be reconciled with environmental protection requirements, such as those in the EU Birds Directive and Habitats Directive (collectively, the "Nature Directives"). ${ }^{4}$

Because parts of estuaries and coastal areas are often already protected as Special Protection Areas (SPAs) under the Birds Directive and as Special Areas of Conservation (SACs) under the Habitats Directive, the sites together comprising the Natura 2000 network, ${ }^{5}$ proposals for new port development have to be based on a thorough understanding of the protection duties contained in these laws. ${ }^{6}$ Most notably, Article 6(3) of the Habitats Directive establishes procedural and substantive requirements to be followed when granting planning permission for projects likely to significantly damage a Natura 2000 site. $^{7}$ Although there is some room for balancing ecological and economic concerns through the application, for example, of the

\footnotetext{
${ }^{4}$ Council Directive 79/409, 1979 O.J (L 103) 1 (EEC); Council Directive 92/43, 1992 O.J. (L 206) 7 (EEC).
}

5 "Natura 2000 Network" is the term used to describe the network of protected areas set out by the Nature Directives. Stretching over $18 \%$ of the EU's land area and over almost $6 \%$ of its marine territory, the network is the largest coordinated network of protected areas in the world. Natura 2000, EUROPEAN COMMISSION, http://ec.europa.eu/environment/nature/natura2000/index_en.htm (last visited March 19, 2017). ${ }^{6}$ European Commission, Guidance on the Implementation of the Birds and Habitats Directive in Estuaries and Coastal Zones 9-10 (Jan. 2011), http://ec.europa.eu/environment/nature/natura2000/management/docs/Estuaries-EN.pdf (last visited March 19, 2017)

${ }^{7}$ See Peter Scott, Appropriate Assessment: A Paper Tiger, in ThE HaBITATS DiRECTIVE: A DeVeloPeR’s ObStacle COURSE? 103 (Gregory Jones ed., 2012). 
exception procedure in Article 6(4) of the Habitats Directive, ${ }^{8}$ the implementation of this derogation provision has caused increasing unease and frustration among port authorities and the companies that work with them. When there is geographical overlap between protected marine or estuarine habitats and potential port extension zones, there can be a sharp rise in the level of conflict between development and protection interests. ${ }^{9}$

In the past, little regard was shown for nature protection areas in ports or in places that might be impacted by port expansion. ${ }^{10}$ This neglect proved troublesome, however, in the face of

${ }^{8}$ See Rebecca Clutten \& Isabella Tafur, Are Imperative Reasons Imperiling the Habitats Directive? An Assessment of Article 6(4) and the IROPI Exception, in THE HABITATS DIRECTIVE: A DeVeloper’s ObStacle Course? 167-182 (Gregory Jones ed., 2012).

${ }^{9}$ See generally ERIC VAN HOOYDOnCK, The IMPACT OF EU ENVIRONMENTAL LAW ON PORTS AND WAterways, Including a Proposal for the Creation of Portus 2010, a COHERENT EU Network of Strategic Port Development Areas (2006).

${ }^{10}$ In its notable ruling on the port expansion in the Stour and Orwell Estuary, the United Kingdom declined to designate inter-tidal habitats that were eligible as SPAs because they were located in future port expansion zones. The European Court of Justice (ECJ) finally held the UK authorities should not have granted consent for development in sites that had been wrongly excluded from SPA consideration on socio-economic grounds. Case C-44/95, Regina v Sec'y of State for the Envt. ex parte Royal Soc'y for the Protection of Birds, 1996 E.C.R. I-03805. See also Hendrik Schoukens \& Hans Woldendorp, Sites Selection and Designation under the Habitats and Birds Directives: A Sisyphean Task, in THE HaBITATs DiRECTIVE IN ITS EU EnVironmental Law ConteXt: EuROPEAn NATURE’S Best Hope? 31-55 (Charles-Hubert Born et al. eds., 2015). 
increased judicial scrutiny of development proposals in national and EU courts in light of the protection duties set out by the Nature Directives. ${ }^{11}$ Notwithstanding the fact that varying standards of review have been applied by national courts that were increasingly asked to respond to challenges to development proposals, ${ }^{12}$ the particularly sharp rise in the number of legal challenges to the construction of new port facilities suggests that this is an especially sensitive subject. ${ }^{13}$ Although for the most part legal proceedings do not succeed in blocking the construction of new port facilities, they do create increased business risks and time delays. ${ }^{14}$ This is the context in which an integrated approach to nature conservation in port areas has been explored - an approach in which biodiversity offsets and restoration actions might play an increasingly important role for aligning further expansion with nature conservation. Offsets are compensatory actions intended to repair the residual impacts that a development will have on

\footnotetext{
${ }^{11}$ Hendrik Schoukens \& Kees Bastmeijer, Species Protection in the European Union: How Strict is Strict?, in The Habitats DiRective In ITS EU EnVIRONMENTAL LAW CONTEXT: European NATURE’s Best HoPE? 129-133 (Charles-Hubert Born et al. eds., 2015).

${ }^{12}$ Geoffrey Wandesforde-Smith \& Nicholas S.J. Watts, Wildlife Conservation and Protected Areas: Politics, Procedure, and the Performance of Failure Under the EU Birds and Habitats Directives, 17 J. OF INT’L WILDLIFE L. \& POL’Y 62 (2014).

13 Roger Morris \& Chris Gibson, Port Development and Nature Conservation - Experiences in England Between 1994 and 2005, 50 OcEan \& COASTAL MGMT. 453 (2007).

${ }^{14}$ Roger Morris, The Application of the Habitats Directive in the UK: Compliance or Gold Plating?, 28 LAND USE POL'Y 361 (2011).
} 
the environment, with the goal of achieving no net loss of biodiversity. ${ }^{15}$ Such actions might involve both the creation of new habitat in locations where it did not previously exist and habitat restoration and re-creation in places where habitats are degraded or have only recently been removed. ${ }^{16}$

In theory, if the progressive use of offsets can align projects with the substantive requirements of EU nature conservation law, recourse to Article 6(4) derogation procedure and its associated risks and delays can be avoided. The notion is that by anticipating the beneficial effects of new habitat creation, or other restoration or enhancement measures that are functionally linked to a project, when the project is assessed, developers can reduce the overall adverse impacts of new development to the point that they are entitled to project approval under Article 6(3). This would effectively side-step the obstacle to development that stems from the unfavourable conservation status of many of the protected areas that are part of the Natura 2000 Network. ${ }^{17}$

The recent Regional Development Implementation Plan for the Port of Antwerp brings these issues into sharp focus. To offset impairments to EU protected nature sites that would result from the construction of a new Saeftinghe Dock on the left bank the Scheldt estuary, the port

${ }^{15}$ See, e.g., Toby Gardner et al., Biodiversity Offsets and the Challenge of Achieving a No Net Loss, 27 CONSERVATION BIOLOGY 1254 (2013).

${ }^{16}$ Roger Morris et al., The Creation of Compensatory Habitat - Can it Secure Sustainable Development?, 14 J. FOR NATURE CONSERVATION 106 (2006).

17 See Hendrik Schoukens \& An Cliquet, Mitigation and Compensation under EU Nature Conservation Law in the Flemish Region: Beyond the Deadlock for Development Projects, UtRECHT L. REV., May 2014, at 194. 
authority proposed an integrated nature creation scheme that would arguably achieve the conservation objectives of EU law more effectively than possible alternatives (Figure 1). The Court of Justice of the EU (CJEU) disagreed and ruled in its 2016 Orleans decision that the nature creation scheme was incompatible with the preventative approach to nature conservation that is at the heart of the Habitats Directive. ${ }^{18}$

[Figure 1 about here]

This article analyses the legal and factual underpinnings of the Orleans case, outlining the most relevant legal considerations to be taken into account when integrating habitat restoration and creation efforts in a spatial planning procedure. It also points to some broader lessons that can be learned about the use of habitat creation and restoration measures to make port development, and by extension other major development proposals, more consonant with EU nature protection law as the CJEU has now defined it.

\section{A Simple Theory: Article 6 of the Habitats Directive as a Benchmark for Project Development in the Context of Natura 2000}

Article 6 of the Habitats Directive contains the basic protection rules for Natura 2000 sites and serves as a logical starting point for a legal analysis of the leeway that is left for project development under European law. Most importantly, the assessment rules included in Articles

\footnotetext{
${ }^{18}$ Joined Cases C-387/15 \& C-388/15, Hilde Orleans and Others v. Vlaams Gewest, 2016 EURLex 583 (July 21, 2016).
} 
6(3) and 6(4) of the Directive establish whether future port developments are likely to be jeopardized because they endanger the long-term survival and/or recovery of the coastal and estuarine habitats present where development is planned. However, the more generic conservation duties laid down in Article 6(1) and 6(2) also have an important bearing on the room left for harmful development in the context of Natura 2000.

\section{Text of Article 6, Habitats Directive}

1. For special areas of conservation, Member States shall establish the necessary conservation measures involving, if need be, appropriate management plans specifically designed for the sites or integrated into other development plans, and appropriate statutory, administrative or contractual measures which correspond to the ecological requirements of the natural habitat types in Annex I and the species in Annex II present on the sites.

2. Member States shall take appropriate steps to avoid, in the special areas of conservation, the deterioration of natural habitats and the habitats of species as well as disturbance of the species for which the areas have been designated, in so far as such disturbance could be significant in relation to the objectives of this Directive.

3. Any plan or project not directly connected with or necessary to the management of the site but likely to have a significant effect thereon, either individually or in combination with other plans or projects, shall be subject to appropriate assessment of its implications for the site in view of the site's conservation objectives. In the light of the conclusions of the assessment of the implications for the site and subject to the provisions of paragraph 4 , the competent national authorities shall agree to the plan or project only after having ascertained that it will not adversely 
affect the integrity of the site concerned and, if appropriate, after having obtained the opinion of the general public.

4. If, in spite of a negative assessment of the implications for the site and in the absence of alternative solutions, a plan or project must nevertheless be carried out for imperative reasons of overriding public interest, including those of a social or economic nature, the Member State shall take all compensatory measures necessary to ensure that the overall coherence of Natura 2000 is protected. It shall inform the Commission of the compensatory measures adopted.

Where the site concerned hosts a priority natural habitat type and/or a priority species, the only considerations which may be raised are those relating to human health or public safety, to beneficial consequences of primary importance for the environment or, further to an opinion from the Commission, to other imperative reasons of overriding public interest.

\subsection{Article 6(1) of the Habitats Directive: The Positive Conservation Principle}

Under Article 6(1) of the Habitats Directive, Member States have an obligation for positive conservation, meaning that they are required to take the conservation measures necessary to ensure continuation of the habitat types and species present on sites listed for protection in 
Annexes I and II of the Directive. ${ }^{19}$ This provision is only applicable to SACs. ${ }^{20}$ The listed sites must be maintained at a favourable conservation status or, as the case may be, must be restored to that status. ${ }^{21}$ Article 6(1) thus has an important bearing on what Member States are required to do for Natura 2000 sites that currently have an unfavourable conservation status. ${ }^{22}$

While the Directive is silent on the question of whether favourable conservation status must be achieved at the individual site level or in aggregate at the national level, ${ }^{23}$ there is no

${ }^{19}$ European Commission, Managing Natura 2000 Sites, The Provisions of Article 6 of the 'Habitats' Directive 92/43/ECC 16 (2000), http://ec.europa.eu/environment/nature/natura2000/management/docs/art6/provision_of_art6_en. pdf (last visited March 19, 2017).

${ }^{20}$ However, according to Article 4(1) of the Birds Directive, the species mentioned in Annex I shall be the subject of special conservation measures concerning their habitat in order to ensure their survival and reproduction in their area of distribution. Council Directive 79/409, 1979 O.J (L 103) 1 (EEC).

${ }^{21}$ EuROPEAN COMMISSION, Establishing Conservation Measures for Natura 2000 Sites (2014), http://ec.europa.eu/environment/nature/natura2000/management/docs/conservation\%20measures. pdf.

${ }^{22}$ Hendrik Schoukens, Atmospheric Nitrogen Deposition and the Habitats Directive: Tinkering with the Law in the Face of the Precautionary Principle? NoRDIC ENVTL. L. J., NO. 2., 25, 28-29 (2015).

${ }^{23}$ However, the CJEU seems to indicate that the conservation objectives are not only to be achieved at national level but must also be realized at individual site level. See Case C-258/11, Sweetman and Others v. Pleanála, 2013 EUR-Lex 220, para. 46; see also Hendrik Schoukens, The Ruling of 
question that Member States must consider ambitious recovery programmes for Natura 2000 sites that now have unfavourable conservation status because of past environmental degradation. ${ }^{24}$ According to the 2015 Nature Report, $85 \%$ of the EU's wetland habitats and $66 \%$ of the EU's marine habitats currently have an unfavourable conservation status, ${ }^{25}$ which is why port authorities have to take the adverse effects of port expansion as well as their autonomous nature recovery and restoration duties very seriously. Whenever protected coastal or marine habitats are already degraded due to a combination, for instance, of dredging, habitat fragmentation, and land conversion in prior decades, restoration objectives must be set at site level. In cases where active on-site management measures have already been implemented or where previous damage substantially limits the room for recovery, more robust and ambitious restoration or re-creation measures may be needed. They could include the re-creation of previously lost wetlands, mud flats, and tidal marshes.

Article 6(1) of the Habitats Directive does not establish an explicit deadline for the achievement of favourable conservation status for adversely affected protected areas. The CJEU recently indicated, however, that conservation and restoration measures need to be put in place no

the Court of Justice in Sweetman: How to Avoid a Death by a Thousand Cuts?, ELNI REVIEW 2 (2014).

${ }^{24}$ An Cliquet, Kris Decleer \& Hendrik Schoukens, Restoring Nature in the EU: The Only Way is Up? in The Habitats Directive In ITS EU EnVIRONMENTAL Law CONTEXT 275 (Charles Hubert Born et. al., eds. 2015).

${ }^{25}$ EUROPEAn ENVIRONMENT AgEnCy, StATE OF NATURE IN THE EU: RESUlTS FROM THE REPORTING UNDER THE NAT http://www.eea.europa.eu/publications/state-of-nature-in-the-eu (last visited March 19, 2017).. 
fewer than six years after a Natura 2000 site is added to the list of Sites of Community Importance. ${ }^{26}$ These conservation and restoration duties apply irrespective of the presence of future expansion plans, which might be prone to further exacerbating the conservation status of the protected habitats or species present in the port area.

\subsection{Article 6(2) of the Habitats Directive: The Non-Regression Principle}

Article 6(2) of the Habitats Directive requires Member States to take appropriate steps to avoid the deterioration of natural habitats and the disturbance of species. This obligation to protect nature under a non-regression principle plays an increasing role in determining how much room for manoeuvre Member States have when contemplating development projects, especially harbour expansions in estuaries that are already degraded.

At first sight, the standard of protection imposed by Article 6(2) appears to be relatively high. ${ }^{27}$ Although there is some confusion about whether Member States have to prohibit all forms of deterioration, including those that may not give rise to significant impacts on a Natura 2000 site, the CJEU has held that "the provisions of Article 6(2) and (3) of the Habitats Directive must be construed as a coherent whole in the light of the conservation objectives pursued by the directive and (...) are designed to ensure the same level of protection of natural habitats and habitats of species." 28

\footnotetext{
${ }^{26}$ Case C-90/10, Comm'n v. Spain, 2011 E.C.R. I-134, para. 64.

${ }^{27}$ Article 6(2) of the Habitats Directive does, however, only rule out disturbances to protected species "in so far as such disturbance could be significant in relation to the objectives of that directive." Council Directive 92/43, 1992 O.J. (L 206) 7 (EEC).

${ }^{28}$ Case C-258/11, 2013 EUR-Lex 220, at para. 33.
} 
Thus, Member States are not allowed to exempt certain categories of activities, such as the on-going maintenance of harbours by dredging, from the application of this non-regression principle. ${ }^{29}$ Even on-going activities, like dredging actions necessary to ensure continued operation of and access to the port facilities, that were authorized before coastal zones or estuarine habitats were designated as Natura 2000 sites have to be scrutinized. ${ }^{30}$ In some instances, where the likelihood of significant effects cannot be excluded, there is an obligation to provide for ex post-monitoring of already permitted activities. ${ }^{31}$

It is generally understood and accepted that non-regression is a strict requirement of EU law and that meeting this obligation may, in effect, require new nature to be created. ${ }^{32}$ Habitat restoration or re-creation measures can also be used if they are necessary to reverse on-going deterioration. ${ }^{33}$ Moreover, the CJEU has held that in some instances Member States may be obligated to declassify a Natura 2000 site if it is irretrievably unsuitable to meet the objectives of the Habitats Directive. ${ }^{34}$ This step must be accompanied, however, by a finding that the degradation in question is the result of a failure in previous years to enforce the protection duties included in other Articles of the Directive. In other words, the mere fact that the environmental

${ }^{29}$ See, e.g., Case C-241/08, Comm'n v. France, 2010 E.C.R. I-01697, paras. 38-39.

${ }^{30}$ See Case C-226/08, Stadt Papenburg, 2010 E.C.R. I-131, para. 49; Case C-404/09, Comm'n v. Spain, 2011 E.C.R. I-11853, paras. 114-60.

${ }^{31}$ Case C-399/14, Grüne Liga Sachsen eV and Others v. Freistaat Sachsen (CJEU, Jan. 14, 2016), paras. $40-46$.

${ }^{32}$ Case C-133/00, Comm'n v. Ireland, 2002 E.C.R. I-5335, para. 31.

${ }^{33}$ Cliquet, Decleer \& Schoukens, supra note 26, at 277.

${ }^{34}$ Case C-301/12, Cascina Tre Pini Ss (CJEU, 3 April 2014), para. 32. 
condition of an estuarine area is deteriorating is not sufficient to declassify it as a protected site and could instead warrant the implementation of additional restoration efforts to halt further deterioration.

\subsection{Articles 6(3) and (4) of the Habitats Directive: The No Net Loss Principle}

Articles 6(3) and (4) of the Habitats Directive set out procedural and substantive assessment duties for plans or projects that are not directly connected with or necessary for the management of a Natura 2000 site. These rules do not impose a general ban on economic development activities. ${ }^{35}$ Their ecological focus does, however, substantially affect the leeway that planning authorities have for issuing permits for developments that might harm a site ${ }^{36}$ and in recent years they have had a marked impact on approval procedures for new developments in Europe's ports. ${ }^{37}$ It is established case law that before a proposed plan or project can be approved it must go through a thorough screening process, or what is called an appropriate assessment, in all those cases where there is the possibility, on the basis of objective information, that the proposal will have a significant effect on a protected site, either by itself or in combination with other projects

or plans. ${ }^{38}$ The appropriate assessment must entail scientifically based analysis and be based on

\footnotetext{
${ }^{35}$ Case C-2/10 Azienda Agro-Zootecnica Franchini Sarl, 2011 E.C.R. I-6561, para. 46.

${ }^{36}$ See Scott, supra note 9, at 103.

${ }^{37}$ See ERIC VAN HoOYdonk, The IMPACt OF EU ENVIRONMENTAL LAW ON PORTS AND WATERWAYS (2006).

${ }^{38}$ Case C-127/02, Landelijke Vereniging tot Behoud van de Waddenzee en Nederlandse
} Vereniging tot Bescherming van Vogels v. Staatssecretaris van Landbouw, Natuurbeheer en Visserij, 2004 E.C.R. I-7405, para. 44. 
concrete, relevant, and precise information. ${ }^{39}$ Potentially cumulative effects linked to existing environmental pressures, such as dredging activities or the operation of industrial activities in port areas, must also be taken into account.

In its landmark ruling in Waddenzee, the CJEU stressed that the authorisation criterion laid down in the second sentence of Article 6(3) rests on the precautionary principle. ${ }^{40}$ Competent national authorities are, therefore, permitted to allow projects or plans to go forward only if they are quite certain, in the light of the applicable conservation objectives and the appropriate assessment, that there will be no adverse effects on the integrity of a protected site. ${ }^{41}$ This stringent view has been reaffirmed by the CJEU in subsequent cases ${ }^{42}$ and it clearly puts the burden of proof on the proponents of potentially harmful developments. ${ }^{43}$ The CJEU has also said that proper weight needs to be given to the impact of a plan or project on site-specific

${ }^{39}$ Case C-441/03, Comm'n v. The Netherlands, 2005 E.C.R I-3043, para. 22.

${ }^{40}$ Case C-127/02, 2004 E.C.R. I-7405, at para. 58.

${ }^{41} I d$. at 59.

${ }^{42}$ See, e.g., Case C-43/10, Nomarchiaki Aftodioikisi Aitoloakarnanias and Others v. Ypourgos Perivallontos, Chorotaxias kai Dimosion ergon and Others 2012 EUR-Lex 560 (Sept. 11, 2012), paras. 109-15.

${ }^{43}$ RALPH FRINS \& HENDRIK SCHOUKENS, Balancing Wind Energy and Nature Protection: From Policy Conflicts Towards Genuine Sustainable Development, in SUSTAINABLE ENERGy UnITED IN Diversity - ChALLENGES AND APPROACHES IN ENERGY TRANSITION IN THE EUROPEAN UNION 84 (L. Squitani, H. Vedder \& B. Vanheusden eds., 2014). 
conservation objectives $^{44}$ and that a more relaxed view of how to protect the integrity of a site would collide with the Directive's precautionary approach. ${ }^{45}$

As a matter of principle, then, development projects that render the protection or, in a context of severe degradation, restoration of a site unsustainable must be rejected. Article 6(4) does stipulate, though, that development can proceed even in the face of a negative assessment. But this can only happen if there is no alternative solution, if the project is deemed to be necessary for imperative reasons of overriding public interest (IROPI), and if all the compensatory measures needed to ensure the overall coherence of the Natura 2000 network have been taken. ${ }^{46}$ These derogation provisions of the Habitats Directive are supposed to be used only as a last resort, ${ }^{47}$ and recent decisions have emphasized that compliance with the three conditions for derogation will be strictly reviewed. ${ }^{48}$

\footnotetext{
${ }^{44}$ Case C-127/02, 2004 E.C.R. I-7405, at para. 47.

${ }^{45}$ Case C-258/11, 2013 EUR-Lex 220, at para. 39-46.

${ }^{46}$ See generally Clutten \& Tafur, supra note 10, at 167.

${ }^{47}$ European Commission, Guidance Document on Article 6(4) of the 'Habitats Directive' 92/43/EEC, Clarification of the Concepts of: Alternative Solutions, Imperative Reasons of Overriding Public Interest, Compensatory Measures, Overall Coherence, Opinion of the Commission 11 (Jan. 2007), http://ec.europa.eu/environment/nature/natura2000/management/docs/art6/guidance_art6_4_en.p df (last visited 19 March, 2017).

${ }^{48}$ FRINS \& SCHOUKENS, supra note 45, at 93-95.
} 


\section{A Complex Reality: The Socio-Economic and Ecological Roots of the Proactive Nature Management Approach Developed for the Port of Antwerp}

\subsection{A Short History Lesson: Unfettered Expansion at the Cost of Nature and Villages} The Port of Antwerp, currently Europe's second largest seaport in total freight shipped after Rotterdam, is situated on the banks of the River Scheldt in Belgium, about 88 kilometres from the North Sea. ${ }^{49}$ Evidence for the existence of a port at Antwerp is dated to the 12 th century. ${ }^{50}$ Much later, Antwerp's potential as major hub was recognized by Napoleon, who ordered the construction of Antwerp's first lock and dock in 1811. By the early $20^{\text {th }}$ century, eight docks had been constructed. They survived the Second World War without major damage. The Belgian government subsequently launched a ten-year plan to expand the port northwards through the construction of both additional docks and related industrial complexes. Bigger locks were built to accommodate large container ships. Along the way, three villages, Oosterweel, Wilmarsdonk, and Oorderen, standing in the way of development, were demolished, and their populations relocated to neighbouring towns, and without much regard to the loss of valuable estuarine habitat and species.

\subsection{Learning by Doing: The Obstacle Course to the Construction of the Deurganck Dock} (1997-2005)

\footnotetext{
${ }^{49}$ For more information, see Port of Antwerp, WIKIPEDIA (Feb. 14, 2017, 1:43 PM), https://en.wikipedia.org/wiki/Port_of_Antwerp.

${ }^{50}$ For more background on the historical development of the Port of Antwerp, see History of the Port of Antwerp, http://www.portofantwerp.com/en/history-port (last visited March 19, 2017).
} 
Starting in the 1960s, the focus of development at the port shifted to the left bank of the river, dubbed "Waaslandhaven," due to its location in the polder region of Waasland in the Belgian Province of East Flanders. The initially ambitious plans for a Waaslandhaven, which encompassed the construction of the Baalhoek Canal, which would have run from Kallo in Belgium through the Drowned Land of Saefthinge (on Dutch territory) into the Western Scheldt, had to be revised, however, because of the economic downturn in the $1970 \mathrm{~s} .{ }^{51}$ By the end of the next decade a more modest Waaslandhaven had emerged (see Fig. 1). Operations there began in the 1990s. Up to this point in time, development plans for the port had faced no significant legal challenges, and expansion plans did not need to be adjusted to account for either existing human settlements (villages) or valuable marshlands or mudflats (nature reserves). This relatively unfettered process of development came to an abrupt halt with the proposed construction of a new tidal dock complex, the Deurganck Dock, in the 1990s.

This dock was to be more than $5 \mathrm{~km}$ long and would entail the destruction of the village of Doel, a 700-year-old settlement along the Scheldt and adjacent to estuarine marshlands designated as a SPA and a SAC by the Flemish Government, which has within the Belgian constitutional system received legislative and executive powers in fields that are connected to its territory, such as the environment, nature conservations and country and land use planning, ${ }^{52}$

\footnotetext{
${ }^{51}$ CARINE Goossens, Edmond Reyn, Tim Soens, Richard Willems \&Ludo Goossens, DoEL, POLDERDORP EN OMGEVING (2015).

${ }^{52}$ As a result of a process of gradual federalisation, Belgium is now a federal state composed of three regions and three (language) communities. Below the regions, there are provinces and municipalities. Since the 1980s, matters relating to the environment, nature conservation, and land use planning largely fall within the exclusive jurisdiction of the Regions.
} 
under the EU Nature Directives. ${ }^{53}$ Construction was temporarily halted by legal challenges brought by a coalition of environmental NGOs and village inhabitants, who alleged that they had received formal promises during the 1970s that the village would remain untouched by any further expansion of the Waaslandhaven. In a landmark decision, the Belgian Council of State held in July 2002 that, since Article 6 of the Habitats Directive had direct effect within the Flemish legal order, the Flemish Government could not use an area proposed for designation as a Site of Community Interest (SCI) under the Habitats Directive as compensation for impairments to existing protected areas caused by the construction of the new dock. ${ }^{54}$ Other NGOs filed complaints with the European Commission, arguing that no appropriate assessment had been carried out for the project as required by Article 6(3) of the Habitats Directive, and that there were no proposals to compensate for the loss of biodiversity the project would cause. ${ }^{55}$ The matter was urgent because work was already underway. ${ }^{56}$ In the face of these pending legal challenges before the Belgian Council of State, the Flemish government decided to ratify the

${ }^{53}$ See Hendrik Schoukens \& Hans Woldendorp, Juridische Moeilijkheden bij Proactieve Natuurontwikkeling: Een Laatste Reddingsboei voor het Polderdorpje Doel?, TIJDSCHRIFT VoOR OMgeVIngsRecht EN - BeleID 97-118 (2014); see also Nina Siegal, Last Holdouts Struggle to Stop Destruction of a Belgian Village, N.Y. TIMES (April 27, 2016), http://www.nytimes.com/2016/04/28/world/europe/belgium-east-flanders-doel.html?_r=0. ${ }^{54}$ Conseil d'État [CE] [Council of State], 2002, No. 2109.563, http://www.conseildetat.be (Belg.).

${ }^{55}$ See Geert Van Hoorick, Natuurbeschermingsrecht. Recente Wetgeving en Rechtspraak Ingevolge de Europese Vogel- en Habitatrichtlijn, NiEUW JURIDISCH WEEKBLAD 1318-22 (2003). ${ }^{56} I d$. 
planning permits legislatively by adopting an Urgency Decree. ${ }^{57}$ The works were deemed to be of overriding public interest under Article 6(4) of the Habitats Directive and an ambitious compensation plan was put forward consisting of both temporary and permanent offset areas totalling some 1,200 hectares that arguably could achieve the conservation objectives established for the Scheldt Estuary. Annual progress reports on the compensation plan would have to be provided to a monitoring committee representing the Flemish Parliament and other relevant actors. ${ }^{58}$ In the light of, among other things, the compensation plan for the Deurganck Dock, the halting of further expansion northwards, and pledges by the Flemish government to do a better job of implementing the Habitats Directive, the European Commission agreed to halt pending infringement proceedings. ${ }^{59}$ And the Belgian Constitutional Court declared that the compensation measures met the requirements of Article 6(4). ${ }^{60}$

${ }^{57}$ Flemish Decree of 14 December 2014 concerning several building permits to which imperative reasons of overriding public interest apply, BELGiAN OfFICIAL GAZETTE, Dec. 20, 2000.

${ }^{58}$ These monitoring results can be consulted on the website of the monitoring committee. See BEHEERSCOMMISSIE NATUUR LinKERSCHELDEOEVER [LEFT BANK NATURE MANAGEMENT COMMITTEE], http://linkerscheldeoever.beheercommissienatuur.be (last visited March 19, 2017). ${ }^{59}$ Hendrik Schoukens, Peter De Smedt \& An Cliquet, The Implementation of the Habitats Directive in Belgium (Flanders): Back to the Origin of Species?, 2 J. FOR EuR. ENVTL. AND PLANNING L. 127, 134-35 (2007).

${ }^{60}$ See Cour d'Arbitrage, 2002, No. 2002/147 (Belg.); Cour d'Arbitrage, 2003, No. 2003/94 (Belg.); Cour d'Arbitrage, 2003, No. 2003/151 (Belg.). 
When a plan was adopted in 2005 to consolidate all the changes stemming from the litigation, the Council of State rejected new lawsuits. ${ }^{61}$ However, the Council also decided in 2012 to quash the previous decision, suspended in 2002, to relocate the village of Doel. ${ }^{62}$ The remaining inhabitants, who numbered only twenty, would be able to stay until the new harbour expansion went ahead. ${ }^{63}$

\subsection{Towards a More Proactive Nature Restoration Approach: From Strategic Vision (2006) to Regional Development Implementation Plan (2013)}

The Strategic Vision for the Port of Antwerp, adopted in 2006, imagined how the development of the port and associated transport facilities might play out up to the year $2030 .{ }^{64}$ Further expansion northwards would occupy an additional 1,000 hectares, particularly to accommodate a new, large-scale tidal dock, called the Saeftinghe Dock, to be built where the village of Doel is now located (see Fig. 1). To circumvent the legal problems that had arisen with the earlier Deurganck Dock, the port authority proposed to consider nature conservation interests proactively to achieve

${ }^{61}$ Conseil d'État [CE] [Council of State], 2007, No. 166.439 (Belg.); Conseil d'État [CE] [Council of State], 2009, No. 191.266 (Belg.).

${ }^{62}$ Conseil d'État [CE] [Council of State], 2012, No. 200.004 (Belg.).

${ }^{63}$ Cours d'Appel [CA] [Court of Appeal], Ghent, May 25, 2012 (Belg.).

${ }^{64}$ VlaAms ministerie Van Mobiliteit en Openbare Werken, Departement Mobiliteit en Openbare Werken, AfDeling HaVen- en Waterbeleid, Tussentijds Strategisch Plan Haven van Antwerpen (2006). 
the conservation objectives for the SACs and SPAs that are present in the areas into which the port would expand. ${ }^{65}$

In the strategic environmental impact assessment for the port's long-term plan, several alternatives were studied. ${ }^{66}$ The zero-alternative and a consolidation scenario had the least damaging impact in terms of nature conservation, environment, and existing settlements, and thus should logically stand out as the most sustainable port development options. ${ }^{67}$ Scenarios according to which the port area would be consolidated, with new developments integrated within the existing boundaries of the port area were rejected as unviable alternatives, however, because without the new Saeftinghe Dock the port could not keep pace with projections for economic growth. ${ }^{68}$ The alternative that was eventually deemed most acceptable did slightly reduce the size of the dock in order to leave one valuable nature area, Putten West, untouched. Otherwise, the anticipated new developments would lead to the loss of 20 hectares of tidal mudflats and tidal marshes (SAC) and to the destruction of 50 hectares of grasslands at Putten-

${ }^{65}$ AeOlus/AfDeling NATUUR, Achtergrondnota Natuur Haven (2006).

${ }^{66}$ StRATEGIC ENVIRONMENTAL IMPACt AsSESSMENT ABOUT THE DEMARCATION OF THE PoRT OF ANTWERP AND ITS SURROUNDINGS (March 7, 2009), available at http://doc.ruimtevlaanderen.be/GRUP/00400/00442_00001/data/RUP_02000_212_00442_00001 _PLNMER_tekst.pdf (last visited March 19, 2017).

${ }^{67}$ Id. at 183.

${ }^{68}$ See FlEMISH GOVERNMENT, Toelichtingsnota Gewestelijk Ruimtelijk Uitvoeringsplan Afbakening Zeehavengebied Antwerpen 63. 
Weide that are breeding grounds for endangered bird species (SPA), the latter one of the few areas in Flanders that still hosts unique sets of salt grasslands. ${ }^{69}$

Instead of opting for derogation under Article 6(4) — a move that would have required the Flemish government to explicitly motivate that the long-term public interest in developing the new dock was greater than that in preserving the Natura 2000 sites - the consensus was that the port should undertake a proactive nature restoration programme. This would arguably obviate the delays that had arisen when Article 6(4) was invoked to complete the Deurganck Dock. ${ }^{70}$ It was also an option that might appear to be a sensible strategy to the stakeholders concerned about the already unfavourable conservation status of most SACs and SPAs. The argument would be that because the expansion of the harbour would be closely tied to the anticipated offset benefits of large-scale habitat creation, restoration, or enhancement measures, the overall environmental impact of the port expansion plan would not be negative. The essence of the proactive nature restoration scheme was that it would replace several isolated patches of habitat already suffering from severe degradation with one robust area of estuarine habitat close to the border with the Netherlands where conservation objectives could be achieved proactively. ${ }^{71}$ This approach found its way into the Regional Development Implementation Plan for the Port of Antwerp adopted in

${ }^{69}$ For more information on this nature reserve, see Putten Weiden, BEHEERCOMMISSIE NATUUR LINKERSCHELDEOEVER, http://linkerscheldeoever.beheercommissienatuur.be/gebieden/puttenweiden (last visited March 19, 2017).

${ }^{70}$ Schoukens \& Woldendorp, supra note 54, at 103-06.

71 The vulnerable grasslands located in Putten-Weiden would be compensated for in the Arenbergpolder, a newly created nature core area located in the Northern part of the Antwerp Port Area. 
$2013 .{ }^{72}$ Almost as soon as this plan was adopted, however, it came under fire. In fact, the Belgian Council of State suspended the plan in December 2013 on grounds that the conditions designed to ensure environmental benefits were not sufficiently integrated into the zoning prescriptions of the plan itself. There was no assurance that significant adverse effects would be avoided, as the second sentence of Article 6(3) requires. ${ }^{73}$ Although this caused quite a stir among the stakeholders involved in the approval process, the decision was not seen as a definitive "no go" for the port's expansion, but rather as a procedural setback. In 2014 an amended version of the plan, including a stricter chronology for the creation of the new nature core areas, was adopted.

\section{A Shifting Legal Context: Nature-Inclusive Design in National and European}

\section{Courtrooms}

In broad terms, the appeal of a proactive nature strategy is not hard to understand. It puts the proponents of development projects in the business of creating nature, rather than destroying it. Assuming the new habitats they create as an integral part of their projects are accepted as being at least as good as or better than the typically degraded habitats they replace, Natura 2000 sites are effectively removed as an obstacle to moving forward. Developers gain more flexibility in dealing with site-specific impacts and conservationists have some reassurance that the overall objectives of the protected site system are being respected. And, as a welcome side effect, the

${ }^{72}$ Flemish Government, Regional Development Implementation Plan 2013 for the Antwerp Port Area, available at https://www.ruimtevlaanderen.be/NL/Diensten/GRUPS/GRUPSDetail/rid/RUP_02000_212_004 42_00001 (last visited March 19, 2017).

${ }^{73}$ Conseil d'État [CE] [Council of State], 2013, No. 225.676 (Belg.). 
derogation clause of Article 6(4), which is viewed by many private and public project developers as an almost insurmountable obstacle to project authorization, is rendered irrelevant. ${ }^{74}$ It does not come into play if appropriate assessments conclude that new habitat renders insignificant the loss of existing, protected habitat.

From a legal perspective, however, the appeal of a proactive nature strategy is less clear, chiefly because it elides the distinction between mitigating adverse effects on the one hand and compensating for them on the other hand. ${ }^{75}$ The view of the European Commission on this point in its guidance documents has been confusing, to say the least. Although the Commission explicitly held in one context that mitigation measures "are aimed at minimizing or even cancelling the negative impact of a plan or project, during or after its completion," 76 it argued elsewhere that mitigation measures are aimed at "enlarging the site or creating new habitats in, or in direct functional relation to, a breeding site or resting place, as a counterweight to the potential loss of parts or functions of the site." 77 Also, it is unclear the extent to which a strict chronology

${ }^{74}$ Schoukens \& Cliquet (2014), supra note 19.

75 Donald McGillivray, Compensating Biodiversity Loss: The EU Commission's Approach to Compensation Under Article 6 of the Habitats Directive, 24 J. OF ENVTL. L. 417, 423 (2012); see also Jonathan Verschuuren, Climate Change: Rethinking Restoration in the European Union's Birds and Habitats Directive, ECOLOGICAL RESTORATION 433-34 (2010).

${ }^{76}$ European Commission, Managing Natura 2000 Sites, The Provisions of Article 6 of the 'Habitats' Directive 92/43/ECC 16 (2000), at 37.

${ }^{77}$ European Commission, Guidance on Strict Protection of Animal Species of Community Interest Under the Habitats Directive 92/43/EEC 47-48 (Brussels, Feb. 2007), available at 
for creating new habitat or restoring affected habitats can actually be implemented before damaging activities are undertaken, and to what extent this might impact the legal qualification of such actions.

\subsection{Nature Inclusive Design in National Courts: Diverging Case Law Developments?}

The Port of Antwerp was not the first place where proactive nature development was tested. The approach, sometimes called nature inclusive design, was first applied in the Netherlands and was subsequently endorsed by several national court rulings. ${ }^{78}$ In 2010 , for example, the Dutch Council of State rejected lawsuits challenging a planning permit for the development of the Markermeer-IJmeer shallow-lake ecosystem. The project combined housing, recreation, surplus water storage, and nature conservation. To offset damage to protected sites, the project provided for the creation of 132 hectares of new mussel beds to help conserve affected birds. The Council of State had no hesitation in seeing the creation of new wetland habitat as a mitigation measure that could be considered in the appropriate assessment and support a finding of no significant effect. ${ }^{79}$ Two years later, the Council reasserted this position, accepting the construction of 22 hectares of foraging and resting habitat as mitigation in the context of an Article 6(3) assessment. ${ }^{80}$ And in another landmark decision involving a proposed extension of the Port of

http://ec.europa.eu/environment/nature/conservation/species/guidance/pdf/guidance_en.pdf (last visited March 19, 2017) (emphasis added).

${ }^{78}$ See Jacqueline Zijlmans and Hans Woldendorp, Compensation and Mitigation: Tinkering with Natura 2000 Protection Law, 10 UTRECHT L. REV. 172, 173-75 (2014).

${ }^{79}$ ABRvS, 26 mei 2010, No. 200901224/1/R2 (Neth.).

${ }^{80}$ ABRvS, 8 februari 2012, No. 201100875/1/R2 (Neth.). 
Eemshaven, the Council, again hinting at flexibility, favoured a progressive interpretation of how a created habitat could be assessed. ${ }^{81}$ These Dutch legal decisions coincided with the development of a proactive nature strategy for the Port of Antwerp, bolstering hopes for a more flexible understanding in Belgium of how appropriate assessments could be conducted.

In fact, however, the Belgian courts proved less inclined to accept the progressive promise of nature inclusive design. ${ }^{82}$ This was strikingly illustrated in a 2013 decision about the legality of a permit for a road bypass that would cut through a Natura 2000 site in the province of Limburg. Because the project specifically included a corridor zone to offset its encroachment on the protected site, it was authorized without resort to the derogation clause of Article 6(4). ${ }^{83}$ In a final ruling on the merits, however, the Belgian Council of State took the view that the creation of a corridor zone could not be accepted as mitigation for the purposes of an appropriate assessment under Article 6(3). ${ }^{84}$

\subsection{Briels: A Clear Interpretation Line?}

To dispel lingering legal uncertainty about exactly how nature restoration and creation measures were to be treated in the context of decision-making about harmful projects under the second sentence of Article 6(3), the Dutch Council of State referred the matter to the CJEU for an

\footnotetext{
${ }^{81}$ ABRvS, 16 april 2014, No. 201304768/1/R2 (Neth.).

${ }^{82}$ See Schoukens \& Cliquet (2014), supra note 19, at 207-10.

${ }^{83}$ See Hendrik Schoukens \& An Cliquet, Biodiversity Offsetting and Restoration Under the European Union Habitats Directive: Balancing Between No Net Loss and Deathbed Conservation?, 21 ECOLOGY \& SOC'Y (2016).

${ }^{84}$ Conseil d'État [CE] [Council of State] 2013, No. 223.083 (Belg.).
} 
advisory opinion. The Council wanted to know the extent to which future restoration measures could be regarded as mitigation in the context of an appropriate assessment for a road development project. In its judgment in Briels, the CJEU declared that future restoration measures could not, as a matter of principle, be considered in the context of an appropriate assessment if their purpose was to offset actual damage to protected habitats. Any other interpretation, it said, would be inconsistent with the preventative principle embodied in the Habitats Directive. ${ }^{85}$

The CJEU based its judgment on two principal assumptions. First and foremost, it assumed that if the future creation of an area of equal or greater size than that adversely affected by a project occurred in a part of the site on which the project had no impact at all, then it could not sensibly be regarded as a measure taken to avoid adverse effects. ${ }^{86}$ Second, such nature creation measures simply attempted to counterbalance the negative impacts that the project would unavoidably create and they were, therefore, properly regarded under the law as compensatory measures within the ambit of Article 6(4). ${ }^{87}$

This aligned the CJEU with Advocate General Sharpston, who had argued that only "measures which form part of a plan or project and which effectively minimize its impact may be taken into account when assessing, in accordance with Article 6(3), whether that plan or project

\footnotetext{
${ }^{85}$ Case C-521/12, T. C. Briels v. Minister van Infrastructuur en Milieu, 2014 EUR-Lex 330 (May 15, 2014).

${ }^{86} I d$. at para. 30.

${ }^{87} I d$. at para. 31.
} 
adversely affects the integrity of that site. ${ }^{98}$ Compensatory measures anticipated under Article 6(4) could, therefore, never be regarded as mitigation, not least because their beneficial effects would only be evident at some point in the future and were, therefore, too uncertain to be part of an appropriate assessment. ${ }^{89}$

\subsection{Towards More Scrutiny in Cases of Outright Habitat Destruction}

The impact of these case law developments quickly became apparent, both in the Netherlands and, to a lesser extent, in Belgium. In a 2014 case involving the extension of a golf course, for example, where 1.8 hectares of priority dune habitat would be destroyed in a neighbouring Natura 2000 site, the Dutch Council of State found that measures aimed at translocating the affected habitats and developing new dune habitats could not be regarded as mitigation in the context of an appropriate assessment. ${ }^{90}$ In a subsequent ruling, the Council again asserted that nature inclusive project designs do not prevent the harmful effects of a project from materializing in the first place. ${ }^{91}$ The same rationale was used to uphold a ruling that the irreparable loss, in a waterway barrier project, of 4.1 hectares of foraging areas for bitterns constituted an adverse

${ }^{88}$ Case C-521/12 T.C. Briels and Others v. Minister van Intrastructuur en Milieu, Opinion (Feb. 27, 2014), para. 32 .

${ }^{89} I d$.

${ }^{90}$ ABRvS, 24 december 2014. No. 201202327/1/R2 (Noordwijkse Golfclub) (Neth.).

${ }^{91}$ ABRvS, 24 december 2014, No. 201300125/1/R2 (Kustversterking Noorderstrand Renesse) (Neth.). 
effect on the integrity of a Dutch SPA, notwithstanding the fact that an ambitious nature development scheme had been integrated into the project plans. $^{92}$

\section{Pending Questions: Adaptive Management in Port Areas as an Ultimate Solution?}

The Briels ruling from the CJEU clearly signalled that a stricter approach to the use of habitat restoration and re-creation measures in the context of Article 6(3) assessments was needed. As long as such measures are used to justify the irreparable destruction of protected patches of habitat, they are to be disregarded in appropriate assessments, especially where designated Natura 2000 sites already exhibit unfavourable conservation status. ${ }^{93}$ The Flemish government remained convinced, however, of the legal soundness of its approach to the future development of the Port of Antwerp, and in response to the suspension of its expansion plan by the Belgian Council of State in 2013 it decided to promise that ecological core areas would be created before any project development in the port area went forward. ${ }^{94}$

\subsection{Adaptive Management in Dynamic Areas, Not Classic Mitigation or Compensation}

\footnotetext{
${ }^{92}$ ABRvS, 11 februari 2015, No. 20140736/1/R6, r.o. 3 (Hoogwater- geul Kampen) (Neth.) .

${ }^{93}$ FRINS \& SCHOUKENS, supra note 45, at 108.

${ }^{94}$ Flemish Government, Regional Spatial Development Plan 2014 for the Antwerp Port Area (Gewestelijk Ruimtelijk Uitvoeringsplan Afbakening Zeehavengebied Antwerpen) (2014), https://www.ruimtevlaanderen.be/NL/Diensten/GRUPS/GRUPSDetail/rid/RUP_02000_212_004 42_00001 (last visited March 19, 2017).
} 
Member States are obligated to restore degraded Natura 2000 sites by Article 6(1) of the Habitats Directive. The Flemish government took the view, therefore, that restoration of the remaining nature areas within the jurisdiction of the Port of Antwerp did not make much sense, given their limited ability to achieve conservation objectives. The better policy was to take whatever steps were needed to ensure that nature conservation objectives would be met both within and outside designated protected areas, and then to adapt that strategy over time as circumstances changed. In the Netherlands, such approaches are often labelled as integrated planning or the programmatic approach, because they rely on a comprehensive set of measures intended to balance economic development with future nature recovery measures. ${ }^{95}$

The proactive nature management strategy linked to port development in Antwerp is a specific application of this adaptive strategy, by locating large nature core areas on the periphery of the expanded port. In the revised Regional Development Implementation Plan for the harbour extension, a stricter chronology was also proposed, whereby the Flemish Agency for Nature and Forest Research would issue an opinion on whether the core areas had been successfully created, and construction of the Saeftinghe Dock would only proceed if these core areas could be shown to be sustainable. This condition would also be included in planning permits for the new port facilities. There would also be additional monitoring requirements, to allow the competent authorities to track the effectiveness of the restoration measures.

It seems clear that an adaptive management approach to Article 6(3) could open the door to a more pragmatic and reconciliatory approach to nature conservation, one that would move appreciably beyond 'deathbed' conservation. Critics have argued that the Nature Directives are

\footnotetext{
95 Zijlmans \& Woldendorp, supra note 80, at 182.
} 
too rigid and dogmatic, because they focus so narrowly on pre-defined conservation objectives. ${ }^{96}$ The CJEU in particular has been criticized for its overly stringent interpretation of the Nature Directives and for standing in the way of a more balanced approach in which the social, economic, and environmental consequences of new developments can be weighed against each other without recourse to the rigid framework of Article 6(4). According to some commentators, a more flexible understanding of nature protection rules would yield greater financial resources and scientific expertise for nature conservation than other scenarios. ${ }^{97}$ It might also help to restore the legitimacy of the Nature Directives, which are, in spite of some positive biodiversity gains, ${ }^{98}$ often depicted as overly burdensome obstacles to moving forward with proposed developments. ${ }^{99}$

\subsection{More Flexibility for Mobile Species in Port Areas?}

Another point of contention arises with respect to the stringent interpretation of the second sentence of Article 6(3), an interpretation that might be acceptable for SACs, which are designated to preserve the ecological characteristics of natural habitats, such as meadows and old growth forests, but may not fit with the more dynamic habitat types with pioneer vegetation associated with SPAs, where there might be more flexibility. A fortiori, the focus in SPAs is less

\footnotetext{
${ }^{96}$ F.H. Kistenkas, Rethinking European Nature Conservation Legislation: Towards Sustainable Development, 10 J. Eur. ENVTL. \& Plan. L. 72, 83-84 (2013).

97 Verschuuren, supra note 77 , at 436-38.

${ }^{98}$ See Guillaume Chapron et al., Recovery of Large Carnivores in Europe’s Modern HumanDominated Landscapes, 346 SCIENCE 1517, 1519; Paul Donald et al., International Conservation Policy Delivers Benefits for Birds in Europe, 317 SCIENCE 810, 813 (2007).

${ }^{99}$ See Wandesforde-Smith \& Watts, supra note 14, at 62-66.
} 
on the preservation and protection of breeding sites and habitats as it is on the conservation of the population of endangered birds that are present on site. Admittedly, the Birds Directive urges Member States to take the measures needed to preserve, maintain, or re-establish a sufficient diversity and area of habitats for all wild bird species. The chief focus, however, is on the maintenance and recovery of the bird populations themselves.

In some port areas, pioneer species such as the Common Tern (Sterna hirundo), the Sandwich Tern (Thalasseus sandvicensis), and the Little Tern (Sternula albifrons) have adapted to dynamic conditions. These species typically have limited habitat requirements and quickly take advantage of newly emerging breeding and nesting opportunities. To conserve its population of terns, for example, the Port of Zeebrugge, located on the North Sea coast in Flanders, created an artificial tern island. The island, first created in 2005 and subsequently extended, aimed to offset the loss of breeding grounds elsewhere in the port area due to previous expansion works. ${ }^{100}$ The idea first arose in the process of designating an SPA in the Port of Zeebrugge ${ }^{101}$ and later found its way into the port's strategic development plan. ${ }^{102}$ The assumption, again, was that this would avoid resort to the derogation clause of Article 6(4), but its feasibility depends heavily on the fact that terns are mobile bird species that easily colonize new pioneer habitats.

\footnotetext{
${ }^{100}$ See Eric VAn HoOydonk, The IMPACT OF EU EnVIRONMENTAL LAW ON PORTS AND WATERWAYS (2006).

${ }^{101}$ Designation Decision Flemish Government (July 22, 2005).

${ }^{102}$ SDP 2009 Port of Zeebrugge (Gewestelijk ruimtelijk uitvoeringsplan 'Zeehavengebied Zeebrugge'), https://www.ruimtelijkeordening.be/NL/Diensten/GRUPS/GRUPS-

Detail/rid/RUP_02000_212_00187_00001 (last visited March 19, 2017).
} 
This flexibility in relation to SPAs is what the Dutch Council of State seemed to endorse when it approved a development in October 2015 that would lead to a reduction of the breeding grounds of several endangered woodpecker species and birds of prey. Because, according to the planning permit, the creation of new feeding and nesting grounds had to take place before the project went forward, the permit was deemed to comply with Article 6(3). Or, to put it differently, the preservation of the bird populations present in the SPA was more important than the conservation of their existing habitats.

\section{The 2016 Orleans Decision of the CJEU on Saeftinghe Dock: A Harsh Lesson for Proactive Nature Development in Port Areas?}

Against the background of the efforts made in Belgium and in Holland to use proactive nature management, or nature inclusive designs, to bring greater flexibility to development project authorizations under Article 6(3), the Orleans decision by the CJEU in July 2016 seems to be, at first sight, a major setback. ${ }^{103}$

\subsection{A Distinction Between Article 6(1) and (2) Requirements and Offsetting Measures} The court began in Orleans by reiterating that the conservation status of a natural habitat is

considered to be favourable ${ }^{104}$ when its natural range and the areas it covers within that range are stable or increasing and when the specific structure and functions needed for its long-term

\footnotetext{
${ }^{103}$ Joined Cases C-387/15 \& C-388/15, 2016 EUR-Lex 583.

${ }^{104} I d$. at para. 35.
} 
maintenance exist, and are likely to continue to exist, into the foreseeable future. ${ }^{105}$ In Sweetman, the CJEU had earlier held that Member States are required to preserve the ecological characteristics of sites which host protected natural habitat types. ${ }^{106}$ There was no way, the CJEU concluded, that the measures at issue in the Antwerp port cases could be regarded as measures ensuring the conservation of the sites affected by the project. ${ }^{107}$ The nature restoration measures the port proposed to take would partially restore and recreate some degraded patches of habitat within the port's jurisdiction, but the overall harbour expansion plan would also entail beyond that the destruction of tens of hectares of protected tidal mudflats, tidal marshes, and salt grasslands. ${ }^{108}$

The restoration measures could not, therefore, be qualified as conservation measures within the framework of Article 6(1). Nor could they be considered as preventive measures, under Article 6(2), given the impairments that would be inflicted on the remaining patches of habitat by the future development of the port. ${ }^{109}$ The court was unwilling, in other words, to consider the beneficial effects of restoration measures in the context of an appropriate assessment for new development. Although this might seem harsh from a project developer's point of view, because it basically prevents competent authorities from considering the beneficial effects of future restoration actions in the context of an on-going authorization for a new plan or project, it

${ }^{105}$ See Article 1(e) of the Habitats Directive; 1992 O.J. (L 206).

${ }^{106}$ Joined Cases C-387/15 \& C-388/15, 2016 EUR-Lex 583, at para. 36.

${ }^{107}$ See also in this respect: Case C-258/11, 2013 EUR-Lex 220, at para.38.

108 Joined Cases C-387/15 \& C-388/15, 2016, at para. 37.

${ }^{109} I d$. at paras. 39-40. 
is hard to argue that future recovery actions are restoration measures if they are aimed at proactively offsetting future damage to existing patches of protected habitats.

Moreover, the CJEU's rejection of a progressive approach to Articles 6(1) and (2) is in line with its previous case law. In a 2010 holding on the French Natura 2000 implementation rules, for example, the court decided that Natura 2000 contracts, aimed at realizing site-specific conservation objectives at a future time, could not exempt building projects from prior assessment. ${ }^{110}$ While the context of the French case is slightly different from that in Orleans, it underlines the reluctance of the court to soften its understanding of what Article 6(3) requires in the context of integral planning. Along the same lines, the European Commission indicated in its 2000 guidance document about Article 6 that, although conservation measures fall outside the scope of the assessment obligation in Article 6(3), "a non-conservation component of a plan or project which includes conservation management amongst its objectives may still require assessment." 111 So, mixed plans, which combine harmful development with restoration actions, still need to be assessed within the framework of the second sentence of Article 6(3). Of course, one might submit that the these recovery actions are autonomous and thus not strictly related to the port development. However, given the fact that the integrated development plan explicitly presented the restoration actions as a justification for the further port expansion, such an approach would not be viable either. In addition, in light of the additional requirement that is in order for offsets (see infra), it remains difficult to entertain that conservation measures that are already

${ }^{110}$ Case C-241/08, 2010 E.C.R. I-01697.

${ }^{111}$ European Commission, Managing Natura 2000 Sites, The Provisions of Article 6 of the 'Habitats' Directive 92/43/ECC 32-33 (2000) (emphasis added). 
required by virtue of Article 6(1) of the Habitats Directive in order to conserve and restore degraded Natura 2000 sites could still be used as offsets for future damaging port development.

\subsection{Limited Room for Adaptive Management Within the Context of Article 6(3)}

The Flemish government strongly argued that, because the restoration measures it contemplated had to be completed before the harbour expansion projects moved ahead, the application of Article 6(4) was pre-empted. There would be no adverse effects, on balance, of the kind that Article 6(3) was intended to identify and assess. And this outcome was guaranteed by a binding timetable for project implementation. The court, nonetheless, disagreed.

The court first reiterated its previous case law, in which it emphasized that an appropriate assessment needs to lead to definitive findings and conclusions capable of removing all reasonable scientific doubts as to the effects of the works proposed on the Natura 2000 sites concerned. ${ }^{112}$ The mere fact, in other words, of binding prescriptions to ensure that newly created nature core areas would become real before the construction of the Antwerp port facilities proceeded was not sufficient to meet the test posed by the precautionary principle. The court also emphasized that, since the wording of Article 6(3) makes no explicit reference to mitigating measures, the effet utile of Article 6 could only be preserved by treating measures taken under Article 6(4) as compensation. ${ }^{113}$ So the rationale of Orleans, correctly understood, is that proactive habitat creation, even it is fully implemented prior to a proposed project moving forward, can only to be counted as mitigation if its beneficial effects can be clearly identified and evaluated in an appropriate assessment. It is inappropriate to assume, in other words, that a

\footnotetext{
112 Joined Cases C-387/15 \& C-388/15, 2016 EUR-Lex 583, at para. 50.

${ }^{113} I d$. at paras. $58-59$.
} 
proposal to create new nature will effectively ensure the favourable conservation status of a Natura 2000 site. That prediction needs to be substantiated by evidence from the field. A strategy of in-advance mitigation or compensation implies a completely different approach to decisionmaking for spatial planning in Europe. The assumption prior to Orleans was that offsetting measures would be implemented after project development began, leaving so-called interim losses unaddressed. Orleans stands this proposition on its head. And it raises other questions.

For example, if restoration measures must now be shown to be effective before projects can proceed, in what sense can they still be regarded as mitigation? Are project developers now required proactively to conclude agreements with competent authorities in which they clearly define the restoration actions that will offset future development, which is yet to be further delineated during the following years? Are project developers obliged to wait until the beneficial effects linked to restoration actions have fully materialized on the ground before they can consider them in the context of an appropriate assessment?

Orleans strongly suggests that the answers to all these questions are affirmative. And that is a ground-breaking turn in a development context where many decision-making procedures have a pro-development bias. The court is effectively urging developers to invest in restoration measures before they have final certainty about the future of their proposals. Even in situations where developers try to negotiate agreements with competent authorities to undertake proactive nature management measures in exchange for implicit consent to develop, no guarantee can be given that projects will finally be authorized because final assessments require evidence that the proactive measures have been implemented and are effectively working. The only way to bypass this strict interpretation of Article 6(3) is to opt for the risks and costs of demonstrating “imperative reasons of overring public interest" (IROPI) under Article 6(4). 
From a nature protection perspective, the CJEU's reassertion of a preventative approach within the context of Article 6(3) has advantages. In the long run, a less demanding mitigation strategy might, for example, undermine the level of environmental protection provided for the EU's most valuable habitats and species ${ }^{114}$-- a fear that is well-founded given the limited effectiveness of restoration measures in the context of offsetting schemes. ${ }^{115}$ Several recent studies have indeed revealed that offset practices often fail to take account of the many uncertainties linked to restoration actions, as well as the considerable time lags involved. ${ }^{116}$ Moreover, an increasing reliance on proposing beneficial restoration measures at the early stages of project decision making risks creating the impression that promises to create new nature can be turned into a "license to trash" 117 the nature that exists. The better principle is to avoid the destruction of the EU's most valuable and threatened habitats from the outset of the development process and to regard it when it does occur as exceptional. ${ }^{118}$

${ }^{114}$ See Schoukens \& Cliquet (2016), supra note 85.

${ }^{115}$ David Moreno-Mateos et al., The True Loss Caused by Biodiversity Offsets, 192 BIOLOGICAL CONSERVATION 552, 552-59 (2015).

${ }^{116}$ See Michael Curran, Stefanie Hellweg \& Jan Beck, Is There Any Empirical Support for Biodiversity Offset Policy?, 24 ECOLOGICAL APPLICATIONS 617, 617-32 (2014).

${ }^{117}$ See Renaud Lapeyre, Géraldine Froger \& Marie Hrabanski, Biodiversity Offsets as MarketBased Instruments for Ecosystem Services?, 15 ECOSYSTEM SERVICES 125, 125-33 (2015).

118 Astrid van Teeffelen et al., Ecological and Economic Conditions and Associated Institutional Challenges for Conservation Banking in Dynamic Landscapes, 130 LANDSCAPE AND URBAN PlANNING 64, 64-72 (2014). 


\section{Wider repercussions: back to the roots of nature protection?}

\subsection{Integrated Port Management}

Several lessons can be drawn from the preceding discussion. The first is that Orleans was a major surprise for the Flemish authorities. They thought the European Commission had endorsed the nature compensation scheme used in the context of the Deurganck Dock as a prime example of sustainable port development. They characterized Orleans, by contrast, as an example of the procedural rigidity that arises when judges fail to understand the many compromises that must be reached before an ambitious nature restoration scheme can be formulated. ${ }^{119}$ Moreover, given the many jobs the new port development would create, an IROPI finding under Article 6(4) seemed to be little more than a procedural formality. The same governmental attitude towards derogation has been evident in other Member States, especially in the United Kingdom, where "it appears relatively easy for developers to establish the existence of IROPI." ${ }^{120}$ And where the strict assessment rules set out by the Nature Directives are often treated as procedural formalities that will have only a limited impact on the final outcome of the decision-making process. ${ }^{121}$

The disappointment with Orleans is understandable in the light of the rigid chronology the Flemish authorities built into their development strategy. In their view, the Saeftinghe Dock could only be developed after the implementation of the nature core areas had been declared “successful." New development of the port area was explicitly made conditional on the

${ }^{119}$ See BEHEERCOMMISSIE NATUUR LINKERSCHELDEOEVER, http://linkerscheldeoever.beheercommissienatuur.be/ (last visited Mar. 19, 2017).

${ }^{120}$ Clutten \& Tafur, supra note 10 , at 176.

${ }^{121}$ Wandesforde-Smith \& Watts, supra note 14. 
successful implementation of the restoration actions. But this overlooks the fact that for some of the habitat types involved, notably the salt grasslands, the viability of offsets would be hard to establish. And in the face of inconclusive monitoring results the project would stall. What the Flemish Government hoped to do was finesse the appropriate assessment by carefully choreographing an integrated project. But what is clear from Orleans and from earlier guidance issued by the European Commission is that the careful sequencing of nature creation with actual development activities is much less important to the success of integrated projects than an early start to coping with the damage projects are going to cause. The Commission said in 2011 that great care needed to be taken in following the sequence of steps outlined in Articles 6(3) and 6(4), noting explicitly that projects expected on the basis of assessment to engender harmful effects could only proceed under the derogation clause, ${ }^{122}$ and that the only way to bypass derogation was to wait until the success of proactive nature management or restoration actions could be demonstrated.

This does not, however, preclude the use of proactive restoration as a "compensatory measure" within the meaning of Article 6(4). ${ }^{123}$ Indeed, the proactive strategy built into the Regional Development Implementation Plan for the Port of Antwerp might even be seen as a model to be followed whenever derogation is invoked. A compensation scheme should be effective, the Commission said, "at the time the negative effects occur on the site concerned.

\footnotetext{
${ }^{122}$ EUROPEAN COMMISSION, Guidance on the Implementation of the Birds and Habitats Directive in Estuaries and Coastal Zones 30 (Jan. 2011).

${ }^{123}$ Joined Cases C-387/15 \& C-388/15, 2016 EUR-Lex 583, at paras. 62-64.
} 
Early implementation is of the essence." ${ }^{124}$ The conclusion has to be then that restoration actions need to be implemented proactively, regardless of whether they are used in the context of Article 6(3) or Article 6(4) of the Habitats Directive.

\subsection{Taking Derogation for Granted}

A second lesson to be drawn from Orleans is that while application of the derogation clause is not per se an insurmountable hurdle for port development or for other major projects, its use is now subject to stringent conditions. As a general rule, the preservation of existing natural heritage at protected sites, such as those in the Natura 2000 Network, is always preferable to taking compensatory measures, ${ }^{125}$ and the mere fact that ambitious compensation schemes are available and have been promised, even if the promise is to implement them on a strict timetable, is not enough to get developments around the hurdle of complying fully with Article 6(4).

Orleans and the cases that preceded it have, thus, made the derogation clause a crucial cornerstone of development decision-making in Europe. If Articles 6(3) and 6(4) are stringently applied, they will rule out the risk that unsustainable developments will adversely affect the EU's most valuable protected sites. This helps to explain why the arguments put forward by the Flemish government in response to Orleans are missing the point. The strict balancing test required to sustain derogation goes beyond an assessment of whether impairment to habitats can be offset. Within the strict context of the alternatives assessment, the focus needs to be on those

\footnotetext{
${ }^{124}$ EUROPEAN COMMISSION, Guidance on the Implementation of the Birds and Habitats Directive in Estuaries and Coastal Zones 30 (Jan. 2011).

${ }^{125}$ See Case C-239/04 Comm'n v. Port., 2006 E.C.R. I-10183, Op. Advocate Gen. Kokott, para. 35.
} 
alternatives that better respect the integrity of Natura 2000 sites. The zero option - that is, doing nothing - must be seriously considered, as well as scenarios in which harbour expansion would be confined or consolidated within the boundaries of an existing port area. ${ }^{126}$ As illustrated by the alternatives assessment that preceded the Regional Development Implementation Plan, public authorities are often inclined to take the economic projections for future port traffic for granted, which renders it unlikely that less intrusive alternatives in terms of ecological damage will prevail in the context of an environmental impact assessment (EIA) or, whenever Natura 2000 sites are damaged, the application of the derogation clause.

Even so, the ruling in Grüne Liga Sachsen buttresses this restrictive approach. There, the CJEU held that the review of alternatives in the context of Article 6(4) "requires weighing the environmental consequences of maintaining or restricting the use of the works at issue, including closure or even demolition, on the one hand, against the public interest that led to their construction, on the other." 127 The economic costs of potential alternatives are "not of equal importance to the objective of conserving natural habitats and wild fauna and flora pursued by the Habitats Directive." 128

Recent case law also makes it clear that the IROPI test embedded in Article 6(4) cannot be met merely because there is some prospect that a development will create economic benefits.

${ }^{126}$ European Commission, Guidance Document on Article 6(4) of the 'Habitats Directive' 92/43/EEC, Clarification of the Concepts of: Alternative Solutions, Imperative Reasons of Overriding Public Interest, Compensatory Measures, Overall Coherence, Opinion of the Commission 7 (Jan. 2007).

${ }^{127}$ Case C-399/14, (CJEU, Jan. 14, 2016), at para. 74.

${ }^{128} I d$. at para. 77. 
In Solvay, the CJEU held that an IROPI interest must be both public and overriding, meaning that it must be of such demonstrable importance that it can clearly overcome the interest in conserving nature. In principle, this is only likely to happen in exceptional circumstances. ${ }^{129}$ But the European Commission has also stressed that a public interest can only be overriding if it is a long-term interest. ${ }^{130}$ Competent authorities must then make a comprehensive analysis of whether a project passes the IROPI test. They cannot limit themselves to accepting the project proponent's claims, which will tend to paint an overly positive picture of project benefits. ${ }^{131}$

In the specific context of the Port of Antwerp, a question arises about whether the shortterm economic gains linked to the construction of an additional container dock should prevail over the preservation of old growth habitats that are already in a degraded state. There also needs to be an evaluation of the economic need for yet another big container dock when other docks are not used to full capacity and economic growth is sputtering. ${ }^{132}$

${ }^{129}$ Case C-182/10, Marie-Noëlle Solvay and Others v. Région Wallonne, 2012 E.C.R., paras. 7576.

${ }^{130}$ European Commission, Guidance Document on Article 6(4) of the 'Habitats Directive' 92/43/EEC, Clarification of the Concepts of: Alternative Solutions, Imperative Reasons of Overriding Public Interest, Compensatory Measures, Overall Coherence, Opinion of the Commission 8 (Jan. 2007).

${ }^{131}$ Clutten \& Tafur, supra note 9, at 181.

132 The Flemish Greens predict that the Saeftinghe Dock would lead to unacceptable environmental and mobility impacts, in an area already characterized by heavy fragmentation, bad air quality, and traffic congestion. See https:/www.groen.be/nieuws/10-feiten-waarom-hetsaeftinghedok-de-verkeerde-keuze (last visited Mar. 19, 2017). 
In short, while proactive nature compensation schemes might, even after the ruling in Orleans, pave the way for a more flexible application of the derogation clause, derogations remain exceptional rather than routine. More pointedly, nature compensation schemes are not a license to carry out a damaging project for which less intrusive alternatives are available, in the absence of a compelling public interest. The Orleans decision is in this sense a clear corrective to the recent tendency in Europe to allow economic factors to pre-empt strict assessments of both damaging projects and of the compensatory measures proposed to offset them. ${ }^{133}$

\subsection{Mitigation vs. Compensation Revisited}

The holdings in both Briels and Orleans make it clear that the benefits of mitigating adverse project effects cannot be claimed if the adverse effects are clear but the benefits of mitigation are prospective, meaning that they have not yet been quantified or realized on the ground. It is still the case that the rescheduling of a project to avoid, for example, interference with the breeding period of a protected species is legitimate mitigation, because it prevents detrimental effects from materializing in the first place. Similarly, realigning the path of a road to avoid vulnerable patches of protected habitat can also qualify as mitigation. Yet as a general rule future restoration actions are not eligible as mitigation measures in the context of Article 6(3) of the Habitats Directive.

More generally, the following conditions now need to be met before a measure can be labelled mitigation:

${ }^{133}$ Nicolas De Sadeleer, Habitats Conservation in EC Law - From Nature Sanctuaries to Ecological Networks, in 5 YEARBOOK OF EuROPEAN ENVTL. L. 215-52 (Thijs F.M. Etty et al. eds., 2005); McGillivray, supra note 75, at 449-50. 
- the measure must be genuinely capable of avoiding or reducing the negative effects of a plan or project, with the aim of ensuring that the integrity of a site is not adversely affected;

- the measure must be strictly related to the same Natura 2000 site and the same habitat or species that is impaired by the project;

- the measure must form an integral part of or be functionally linked to the plan or project that impairs a Natura 2000 site;

- the measure must not be part of the conservation measures Member States are required to implement by Article 6(1) and/or 6(2) of the Habitats Directive;

- the measure's effectiveness in avoiding or reducing the negative effects of a plan or project cannot be uncertain. ${ }^{134}$

Measured against these criteria, do sophisticated schemes to create markets in banked biodiversity offset credits - often dubbed "habitat/species banking" - constitute mitigation? ${ }^{135}$ In some ways the proactive nature restoration strategy proposed for the Saeftinghe Dock could be interpreted as an attempt to implement this rationale, although there was no suggestion that credits could be traded outside the Port of Antwerp.

The key difficulty here is that, although habitat banking might support a proactive approach to mitigation or compensation, and avoid interim losses, it does not pass the test of "like for like"

${ }^{134}$ RalPh H. W. Frins, Mitigatie, Compensatie en SALdERING IN HET OMgEVINGSREChT (2016).

${ }^{135}$ See, e.g., Joseph W. Bull et al., Biodiversity Offsets in Theory and Practice, 47 ORYX 369, 369-80 (2013); Géraldine Froger et al., Towards a Comparative and Critical Analysis of Biodiversity Banks, 15 ECOSYSTEM SERVICES 152, 152-62 (2015). 
offsets that both the CJEU and the European Commission have endorsed. ${ }^{136}$ One can imagine situations where port authorities purchase land in advance in order to create new breeding grounds for highly mobile species, such as protected terns, in order to offset future development actions on existing breeding grounds, which the birds will readily abandon. But this is a very limited set of circumstances, and one in which it is quite clear that new breeding grounds will work just as well as those that are lost. In other cases, involving old growth habitats or less mobile species, for example, the elegant solution that works for the terns is unlikely to be available. Or, if it is available, it would entail considerable delays that would not make it an attractive option for project developers.

To some extent, the elaborate efforts made proactively to offset the damage to existing salt grasslands to accommodate the Saeftinghe Dock might be tagged as a major step towards habitat banking. They even seem to comply with the "like for like" rationale. But there are so many uncertainties surrounding the feasibility of recreating threatened salt grasslands in other locations outside the port area that it remains doubtful whether such progressive types of restoration strategies are consistent with the precautionary principle. Either way, the ruling in Orleans clearly

${ }^{136}$ European Commission, Guidance Document on Article 6(4) of the 'Habitats Directive' 92/43/EEC, Clarification of the Concepts of: Alternative Solutions, Imperative Reasons of Overriding Public Interest, Compensatory Measures, Overall Coherence, Opinion of the Commission 14 (Jan. 2007). See also EFTEC and IEEP, The Use of Market-Based Instruments for Biodiversity Protection - The Case of Habitat Banking, Technical Report for European Commission DG Environment 117-19 (Feb. 2010), http://ec.europa.eu/environment/enveco/pdf/eftec_habitat_technical_report.pdf (last visited Mar. $19,2017)$ 
indicates that the room for more flexible offsetting schemes, such as habitat banking, remains extremely limited within the realm of the Nature Directives.

\subsection{Additionality: Achieving Net Gains in Comparison with the Baseline Scenario}

All the measures incorporated into the Regional Development Implementation Plan for the Port of Antwerp were intended to achieve two goals at the same time. First, they would arguably achieve favourable conservation status for the Natura 2000 sites affected and, second, they would offset the impairment of those sites. However, under Articles 6(1) and 6(2) of the Habitats Directive, authorities were already under an obligation to implement restoration and conservation measures to reverse on-going habitat degradation in the port area. In recent years, for example, both Flemish and Dutch authorities have intensified dredging activities to guarantee optimum accessibility to the Port of Antwerp. Hence the Article 6(1) and 6(2) measures were already necessary to avoid infringement actions by the European Commission. ${ }^{137}$ Some of the nature core

${ }^{137}$ The Estuary Development Outline (2010) was approved by both the Dutch and Flemish governments in March 2005. It aimed at resolving the political tensions that have persisted for centuries between the Netherlands and the Flemish Region as to the management of the Scheldt Estuary, which is vital for the further development of the Port of Antwerp. The newly established policy strategy laid down a long-term strategy, to be reached by 2030 , which has three main focal points: safety (maximum protection against flooding in the region), accessibility (optimum accessibility of the harbours on the Scheldt estuary via dredging activities), and natural environment (a dynamic, healthy natural environment). Inter alia, the Outline established clearcut conservation objectives for the SACs and SPAs present in the Scheldt Estuary. These commitments were then further translated in the 2005 Scheldt Treaties, which have been signed 
areas included in the development plan for the Port of Antwerp were meant to comply with the conservation duties enshrined in Articles 6(1) and 6(2). ${ }^{138}$

To what extent were the restoration measures included in the Regional Development Implementation Plan for the Port of Antwerp in line with the additionality requirement of European nature conservation law, a requirement which holds that mitigation or compensation measures taken in relation to new developments must provide a net positive contribution to conservation, above and beyond whatever contribution was needed to meet existing conservation commitments? The appropriate assessment carried out for the port expansion did not explicitly address this issue, even though the additionality principle has long been regarded as crucial to meeting the no net loss objective of European nature conservation policy, which holds that only those biodiversity benefits that are additional to a properly established baseline can count as valid mitigation, compensation, or offsets. ${ }^{139}$

The decision in Orleans preserves this view and, thus, perhaps inadvertently, closes the door on a so-called double dipping tactic whereby restoration measures needed to comply with and ratified both by the Netherlands and the Flemish Region. At the Flemish level, the so-called Sigma Plan further implemented the sustainable approach to the Scheldt Estuary, by combining and balancing its natural, economic and socio-cultural functions. See http://www.vnsc.eu/publicaties/wetenschappelijke-publicaties-en-rapporten/100ontwikkelingsschets-2010-schelde-estuarium.html (last visited Mar. 19, 2017).

${ }^{138}$ See Joint answer given by Mr. Potočnik on behalf of the Commission to the Written Questions E-006402/11, E-006507/11, P-006822/11 (Sept. 15, 2011).

${ }^{139}$ Martine Maron et al., Locking in Loss: Baselines of Decline in Australian Biodiversity, 192 BiologicAl CONSERV. 504, 504-12 (2015). 
obligations under Articles 6(1) and 6(2) of the Habitats Directive can also be counted as offsets for the adverse effects of a project under Articles 6(3) and 6(4). ${ }^{140}$ This rationale is understandable because the EU's ambitious nature restoration targets, ${ }^{141}$ which aim for net gains, will not be met if restoration actions needed to stall on-going deterioration are immediately reused to offset the harmful effects of new developments. ${ }^{142}$

From a policy perspective, the focus should be, first, on making degrading biodiversity more resilient, and only after this has been achieved through a proactive nature restoration strategy, should permits be issued for new and potentially harmful developments under Article 6(3). Or, alternatively, one should clearly indicate that the purported offsets go beyond the autonomous conservation or restoration measures necessary to comply with Article 6(1) and 6(2) of the Habitats Directive. Admittedly, while some might submit that the rigidity of the CJEU in this respect could urge project developers such as port authorities to invest less in restoration

${ }^{140}$ Joined Cases C-387/15 \& C-388/15, 2016 EUR-Lex 583, at para. 42.

${ }^{141}$ EuRoPEAn COMMISSION, Communication from the Commission to the European Parliament, the Council, the Economic and Social Committee and the Committee of the Regions, Our Life Insurance, Our Natural Capital: An EU Biodiversity Strategy to 2020 (2011, COM (2011) 244 final). The Council of the European Union endorsed the Biodiversity Strategy in its June 21, 2011 decision (EU Biodiversity Strategy to 2020 - Council Conclusions, 11978/11).

${ }^{142}$ The European Commission already specified in its 2000 Guidance on Article 6 of the Habitats Directive that "[m]easures required for the 'normal' implementation of the 'Habitats' or 'Birds' directives cannot be considered compensatory for a damaging project." EUROPEAN COMMISSION, Managing Natura 2000 Sites, The Provisions of Article 6 of the 'Habitats' Directive 92/43/ECC $44-45(2000)$. 
actions, and ultimately put in jeopardy the conservation goals of the Habitats Directive itself, the rationale of the EU judges effectively contributes to averting a further net loss. Moreover, should more flexibility be shown under the habitat assessment rules, the risk exists that ecological restoration would become an almost exclusively development-driven activity. Accordingly, environmental degradation could become a prerequisite for finding the necessary financial goodwill and means to consider large-scale restoration efforts.

\section{Conclusion}

This analysis shows that, when located near Natura 2000 sites, port developments in Europe and, by extension, other major development plans and projects in Europe, can be difficult to reconcile with the preventative approach to nature conservation that the CJEU has determined is fundamental to the EU Nature Directives. Developers, and more specifically port authorities in Belgium and the Netherlands, have shown a remarkable willingness to make nature conservation measures an integral part of their planning for expansion. But this has not substantially alleviated the frustration they feel with the court's steadfast embrace of the precautionary principle. The CJEU's refusal to accept the legal soundness of an integral approach to project-linked nature restoration within the specific context of Article 6(3) of the Habitats Directive continues to impede permitting procedures. Even if nature management and restoration actions are proactively implemented, they can only be regarded as compensation measures in the context of the derogation clause. Proposals to restore or re-create natural habitats cannot, as a matter of law in Europe, be treated as a license for proceeding with projects for which less harmful alternatives exist or for which compelling and overriding reasons of public interest cannot be demonstrated.

It remains to be seen whether and how port expansion schemes and other major project developments can move forward if they entail the destruction of estuarine and marine habitats in 
Europe that are already in an unfavourable conservation status. The Port of Antwerp case indicates that, at least in some instances, the options for competent authorities to coordinate proactive nature conservation measures with future actions likely to be harmful to protected areas may be severely restricted. Critics might predict that this alleged rigidity undercuts the legitimacy of the Nature Directives. One might even go so far as to say that, because biodiversity conservation goals carry limited political weight in Europe, harmful developments are inevitable, no matter the time, energy and expense involved in subjecting them to procedures of analysis and assessment. In which case, why not accept that development proposals including robust ecological restoration measures are making the best of a bad situation, and let such projects proceed?

The argument against this very tempting suggestion is that the benefits of nature restoration and re-creation measures are, under recent case law, too uncertain to turn around the poor conditions that now prevail in many, if not most, of Europe's endangered habitats. The courts are of the view that it makes little sense to destroy the nature that remains in exchange for gains that are speculative. And this in turn strongly suggests that European port authorities, and project developers and planning authorities more generally, are better advised to read Orleans as an incentive to step up their efforts to restore the degraded protected areas within their jurisdictions, thus making them more resilient in the long run to absorb the environmental pressures that major new development projects are bound to entail. More innovative strategies which fail to observe the mitigation hierarchy are liable to be defeated in court.

There is certainly nothing in Orleans that would prevent developers from proactively restoring or recreating nature, both on-site or off-site, near protected areas that stand to be affected by future development actions. And for project developers who operate in a context where degraded Natura 2000 sites are sure to be affected by their future plans, such ambitious 
and proactive restoration strategies make even more sense. Instead of wasting time and money with ad hoc mitigation strategies of dubious legal soundness under Article 6(3), developers might be better off securing "restoration deals" with competent authorities in which both sides stipulate an "environmental baseline" against which future improvements to habitats and species can be measured. If proactive restoration goes beyond existing conservation duties and yields results before new planning procedures are initiated, it can be viewed as an additional instrument for achieving the EU's 2020 biodiversity targets while justifying further development, even in the context of Natura 2000 sites. ${ }^{143}$ The downside is that under Orleans developers cannot reasonably anticipate the benefits of restoration measures that have yet to be proven successful on the ground, and competent authorities cannot, therefore, give developers definitive assurances that their projects will be able to move ahead. In other words, project developers are required to invest in further restoration actions without having received formal assurances that their future development plans can go ahead. Still, while the latter strategy might appear anachronistic, it might ultimately still constitute a more sensible pathway towards genuine sustainable development.

Be that as it may, as long as EU judges are unwilling to depart from the mitigation hierarchy that implicitly underpins Article 6(3), developers ought to distinguish clearly between

${ }^{143}$ It is provided that "by 2020 , ecosystems and their services are maintained and enhanced by establishing green infrastructure and restoring at least 15\% of degraded ecosystems." Cliquet, Decleer \& Schoukens, supra note 26, at 268. See also ANASTASIA TELESETSKY, AN CLIQUET \& ASHFIN AKHTAR-KHAVARI, ECOLOGICAL RESTORATION IN INTERNATIONAL ENVIRONMENTAL LAW (2016). 
measures that are needed to comply with the restoration duties required of them under Article 6(1) and those that are taken as offsets under Articles 6(3) and (4).

And when the derogation provision of Article 6(4) is invoked, Orleans is very clear that developments can only go ahead when there has been a very careful and explicit weighing and balancing of the conservation value of existing patches of habitat. This might be viewed as the imposition of an unnecessary administrative burden on major infrastructure projects such as port expansion, which are generally believed to be the key to future economic prosperity of a region or even an entire country. But from an environmental point of view it is highly desirable, especially in cases where projects entail the destruction of villages and the further degradation of protected areas that are already stressed. Orleans is thus a corrective to environmental assessments that in the past have been prone to give too much weight to the economic growth projections on which proposed projects are premised.

Orleans also represents a call to look much more closely at other, less intrusive project alternatives to those proposed by the developer, and to favour scenarios that conserve or restore existing patches of habitat in protected areas. Individual development proposals ought to be framed in the wider perspective of sustainable development goals, so that competent authorities and other stakeholders can objectively assess the extent to which economic interests are being allowed to prevail over the in situ conservation of vulnerable patches of habitat. And this presupposes that, at least in some instances, projects will be denied because they cannot be reconciled with the continued existence of viable Natura 2000 sites. The very fact that the Flemish government, in reaction to the decision in Orleans, has recently announced that it will carry out a more comprehensive examination of all the available alternatives for the planned port 
expansion only underscores this point. ${ }^{144}$ Instead of taking future port expansion as a steadfast premise, the new planning procedure will tackle the more broader question on how to achieve an increase of the container capacity in the wider ecological and societal context. ${ }^{145}$

In summary, while the ruling in Orleans leaves limited room for developers to formulate and proceed with proposals that will adversely affect protected areas in Europe, it is a powerful reminder to developers that they have serious responsibilities to ensure sustainable development. Additional impairments to Natura 2000 sites that already have legal protection are only going to be permissible when restoration actions render them resilient to further change or when the overriding reasons of public interest for further impairing those sites have been conclusively and transparently demonstrated. This entails that restoration actions are no longer to be treated as a “one-size-fits-all-solution” for troublesome permitting procedures. Orleans makes the prevention of future significant damage to existing protected areas a vital component of European environmental law and policy, going forward. Given that the European Commission has recently

${ }^{144}$ See Antwerps Saeftinghedok niet Langer Heilig Huisje, http://www.tijd.be/nieuws/archief/Antwerps_Saeftinghedok_niet_langer_heilig_huisje.98411771615.art (last visited Mar. 19, 2017).

${ }^{145}$ Note that the Flemish Government did not wait for the final annulment of the strategic development plan by the Belgian Council of State (Council of State (2016), no. 236.837) to initiate a new strategic development procedure in order to accommodate the demands of the Antwerp Port Authority for additional container capacity within the context of the Port of Antwerp. This will be done through the integral planning procedure set out by the Decree of 25 April 2014 on complex projects, which has set out a more participative and sequential approach to spatial planning for large infrastructure project in the Flemish Region. 
completed the "Fitness Check Evaluation" of the Nature Directives, ${ }^{146}$ holding that the protection rules are "highly relevant" and "fit for purpose," 147 the preventative approach prevailing within the context of Article 6(3) of the Habitats Directive is likely here to stay. It remains to be seen to what extent the recent case law developments will also signal a paradigm shift towards more sustainable development proposals in Europe, but that is clearly the direction in which the recent jurisprudence points.

${ }^{146}$ According to the European Commission, the so-called fitness checks provide an evidencebased critical analysis of whether EU actions are proportionate to their objectives and deliver as expected. They cover environmental, economic, and social aspects, and concern all EU policy areas. In the field of environment policy, the Commission has completed fitness checks of the EU legislation on freshwater and on waste. The fitness check of the EU Birds and Habitats Directives was initiated back in 2013. See European Commission, Communication from the Commission to the European Parliament, the Council, the European Economic and Social Committee and the Committee of the Regions, Regulatory Fitness and Performance (REFIT): Results and Next Steps (2013), http://ec.europa.eu/smart-regulation/docs/20131002-refit-annex_en.pdf ((last visited Mar. 19, 2017).

${ }^{147}$ European Commission, Commission Staff Working Document Fitness Check of the EU Nature Legislation (Birds and Habitats Directives) (2016), http://ec.europa.eu/environment/nature/legislation/fitness_check/docs/nature_fitness_check.pdf (last visited Mar. 19, 2017). . 


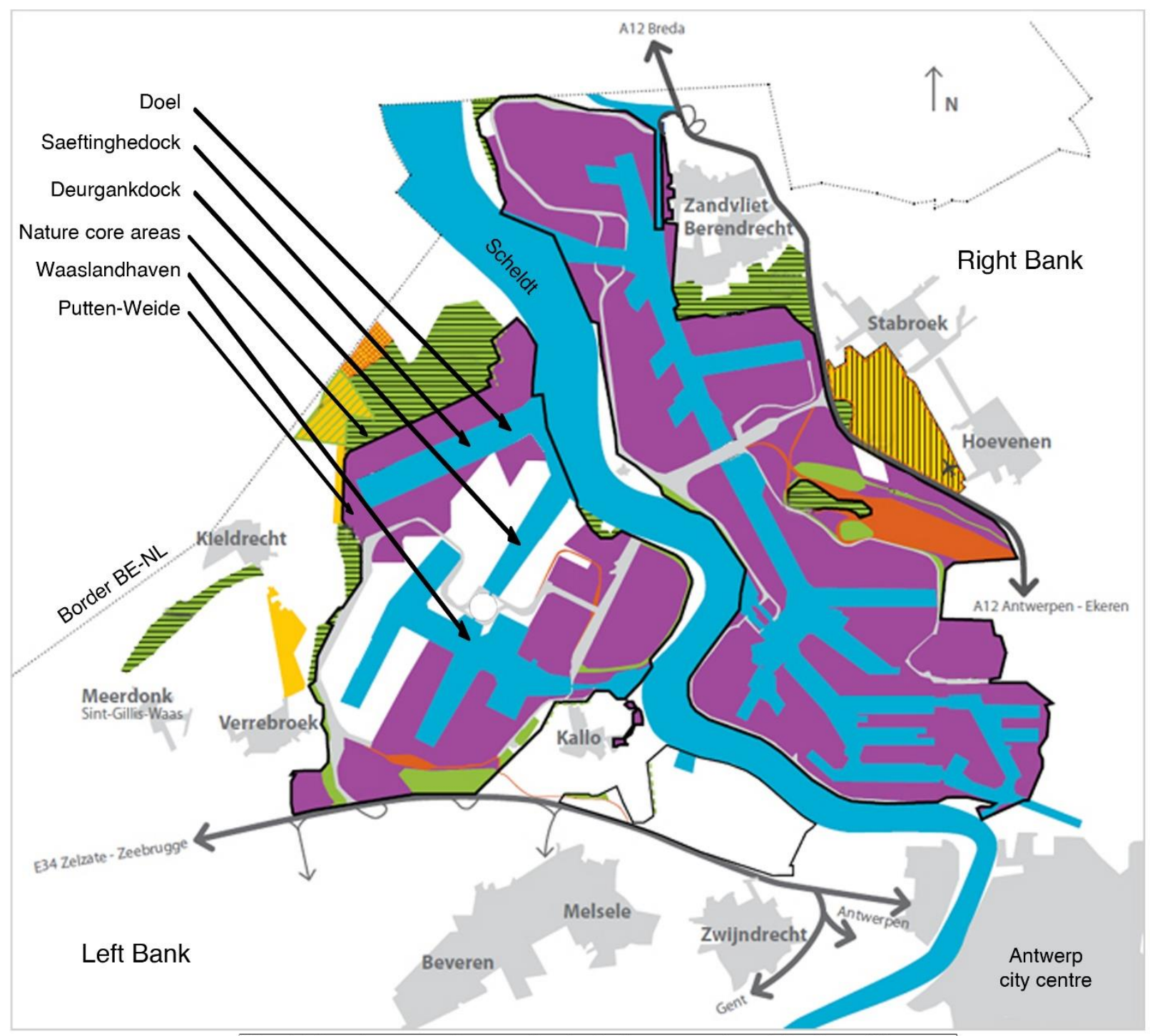

Spatial Developement Strategy for the further expansion of the Port of Antwerp

Figure 1 